\title{
Islamic Representation in the Literature of Betawi Local Colors
}

\author{
Ahmad Bahtiar \\ Syarif Hidayatullah State Islamic \\ University \\ Jakarta, Indonesia \\ ahmad.bahtiar@uinjkt.ac.id
}

\author{
Rosida Erowati \\ Syarif Hidayatullah State Islamic \\ University \\ Jakarta, Indonesia \\ rosida.erowati@uinjkt.ac.id
}

\author{
Novi Diah Haryanti \\ Syarif Hidayatullah State Islamic \\ University \\ Jakarta, Indonesia \\ novi.diah@uinjkt.ac.id
}

\begin{abstract}
Many values of Islamic teachings influence the traditions and culture of the people in Indonesia, one of which is the Betawi community. This study intends to reveal the representation of Islam in the local color literature of Betawi depicted in a short stories collection of Terang Bulan Terang Terang Kali: Cerita Keliling Jakarta by S.M. Ardan. With representation theory and the sociology of literature approach, this qualitative research reveals various Islamic values in the Betawi community contained in these literary works. Based on the research, the value of Islamic teachings presented in this collection includes the identity of the Betawi people through the naming of their characters and their greetings, also their education, attitudes and profession or job being undertaken.
\end{abstract}

Keywords: representation of Islam, Betawi local colors, Terang Bulan Terang di Kali: Cerita Keliling Jakarta, S. M. Ardan

\section{INTRODUCTION}

A good story is supported by a sharp and clear background. These characteristics justify and testify where indeed a story takes place. The sharper and clearer description of this cultural background would result in the vivid local color based on the social culture in a defined time and place [1]. Local color is part of the structure of literature, especially one aspect of the setting, atmosphere, and use of language. As part of physical setting and space, local colors are associated with geography which includes local cultural characteristics, such as customs and rituals, and even the lexical-idiomatic interference of regional languages into the Indonesian language used therein [2].

Furthermore Purba [3] describes local color literature characterized by characteristics of regional language usage, regional language style, depiction of background, character, characterization, how to dress, eat, drink, customs, beliefs, religious beliefs , and philosophy of life.

The use of local colors in Indonesian stories has been started since the beginning of the history of Indonesian literature. If we look at the authors' works, commonly known as the "Balai Pustaka Generation", the local colors of Minangkabau are very sharp in the stories of authors from that province.

Therefore, it is not a new symptom when local colors from other regions appear in the Indonesian literary repertoire. Call it the local colors of Dayak in Upacara (by Korrie Layun Rampan), Javanese in Pengakuan Pariyem (by Linus Suryadi AG), Ronggeng Dukuh Paruk (by Ahmad Tohari), Burungburung Manyar (by Y.B. Mangunwijaya), and Para Priyayi (by Umar Kayam), Malay in Parang Tak Berbulu (by Raudal Tanjung Banua) and Sandiwara Hang Tuah (by Taufik Ikram Jamil, 1997), also Balinese in Tarian Bumi (by Oka Rusmini).

However, very few authors raise the local colors of Jakarta (Betawi), though since hundreds of years ago Jakarta has become a melting pot and residence for various tribes and nations. This city is a representation of Indonesia in the true sense. Talking about Jakarta in her past and present is endless. Just mention demographic aspects, urban morphology, environment, traffic to floods. These recent problems stem from a variety of issues that are almost the same in the past.Among the few are S.M. Ardan whose real name is Shamardan. Born in Medan on February 2, 1932 , but since he was a few months old he lived in Jakarta until he died, November 26, 2006. Besides being known as the "Indonesian Film Walking Encyclopedia", he was a Betawi writer. He did not only writes about Betawi in the form of poetry or stories but also fosters Lenong theater, Betawi theater since the 1970s in Taman Ismail Marzuki (TIM/a cultural center in Central Jakarta) and TVRI (Indonesian National Television). Because of that, according to Maman Mahayana, S.M. Ardan is better recognized by Betawi artists than writers [4]. As a writer, he wrote a collection of poems Ketemu di Jalan (1956) with Ajip Rosidi and Sobron Aidit. Then came the novel, Nyai Dasima (1965), which had previously been serialized in the Warta Berita (1960). The novel is a reprint of the story of the work of G. Francis. Previously the earliest drafts of the play were published in Drama magazine, no. 2, I, 1953. His name became known after this publishing.

Ardan's work that depicts the Betawi people and their problems is Terang Bulang Terang di Kali in Betawi travelling story (2007). This collection of short stories is considered as the beginning of the use of Betawi dialect in a whole story. The Betawi language is used not only to build the background but is used in the dialogues (conversations) in almost all the stories. Even though creating a polemic in the beginning, the use of the Betawi dialect was accepted as part of introducing Betawi cultural traditions in addition to new possibilities for Indonesian literature. Ardan's 
steps were followed by other authors in the area outside Betawi. Judging from this aspect, Ardan can be considered as an initiator.

Betawi community is known with its labelling as a moslem community. Therefore Islam plays an important role in the life of the Betawi community. The origin of this community is still in debate but the nature is unarguably moslem. Thus, it is very important to see the influence of Islam in the description of this community in the fiction realm. As S.M. Ardan would show in his early works to introduce the Betawi community and its cultural landscape.

\section{LITERATURE REVIEW}

\section{A. Theoretical Framework}

In the Representation book: Cultural Representation and Signifying Practices, Stuart Hall (2003) reveals "representation is the production of the meanings of concepts in our minds through language. It is the link between concepts and language which allows us to refer to either real-world objects, people or events, or indeed to imaginary worlds of fictional objects, people, and events [5]."

Furthermore, Hall revealed that representation works through a system consisting of two important components, namely concepts in mind and language. This system can work well, when certain groups have the same background knowledge that creates almost the same understanding. That is why it is produced, displayed, used, and understood in certain social contexts.

In line with Hall, Barker revealed that representation is how the world is constructed and presented socially too and by ourselves. Cultural repentance and meaning, according to him, have material properties. Among them are in every writings, images, and books that are produced and understood in a specific social context [6]

In addition to representation, this study uses the theory of sociology of literature. Sociology is one of the studies in literary science. Siswanto defines the sociology of literature as an interdisciplinary study between literature and sociology (Siswanto, 2008). Meanwhile, Sapardi Djoko Damono revealed that literary sociology is an approach that considers social aspects [7]. Furthermore Endraswara (2008) defines the sociology of literature as a study of the work of literature which includes (a) objective scientific and human scientific studies, (b) the study of social institutions through literature and vice versa, (c) the study of social processes, which is how the community works and how the community lives [8]. From the definition above it can be concluded that the sociology of literature is an approach that looks at literary works by prioritizing the study of social values both contained in literature and in the view of the author.

In the study of literary sociology Swingewood divides literary sociology over (a) Sociology and literature, (b) social theories about literature, and (c) literature and structuralism and (d) methods. In the sociology of literature three approaches are discussed, First, the approach that sees literature as a sociocultural document that reflects one era. Secondly, the approach of R. Escarpit which resulted in aspects of the success of literary works, especially the social position of writers. Third, the approach that connects with Leo Lowenthal who sees a society's acceptance of the literary work of certain writers [9].

Local color literature is by definition a fiction that set its focus on characters, dialect, customs, topography, and other features that belong to a certain region. "In local color literature, one finds the dual influence of romanticism and realism, since the author frequently looks away from ordinary life to distant lands, strange customs or exotic scenes, but retain through minute detail a sense of fidelity and accuracy of description" [10].

\section{B. Research Method}

This study uses a qualitative descriptive method to find out how the representation of Islamic values in Betawi local color. Qualitative methods show the nature of values whose data sources are works, texts, and formal data used are words, sentences, and discourses [11]. Because of its descriptive nature, everything in the form of a sign system is important and influences each other.

The primary data source used in this study is collection of short stories Terang Bulan Terang di Kali: Cerita Keliling Jakarta by SM Ardan (200 pages). This collection was first published under the title Terang Bulan Terang di Kali (1955) by the publisher of Gunung Agung and reprinted by Pustaka Jaya (1971).

To enrich the story of Betawi, J.J. Rizal added 12 short stories by Ardan, which were still scattered in various publications (Mimbar Indonesia, Kisah, Indonesia, Tjerita, and Siasat) and personal documentation. The scattered works are put together in the "Story Around Jakarta" section and become an addition to Ardan's previous collection of short stories. For that the Terang Bulan Terang di Kali: Cerita Keliling Jakarta contains 22 short stories consisting of two parts which are stories from the first publishing in 1955 and the addendum being collected by J.J. Rizal (2007).

Secondary data sources are journals, newspapers, articles, and other books related to the research title that supports research.

The approach used in this study is the sociological approach to literature. The literary sociological approach that is most widely practised today pays attention to aspects of literary documents based on the idea that literature is a mirror of its era [11]. Wellek and Warren revealed that there were three main problems of literary classification. First, the author's sociology, namely social background, author status, and author's ideology. Second, the sociology of the work that disputes the work itself. Third, readers' 
problems and the social impact of literature. For the purpose of this research, the second type will be used.

\section{DISCUSSION}

Ardan in this book tries to elevate the local colors of Betawi with all their daily lives, including its religious side, which elevates Islamic values in everything. Some of the stories in Ardan's work are set in Central Betawi such as Tanah Abang, Senen, Kramat, Harmoni, Glodok, and Kwitang.

Betawi Islamic identity is characterized by the characteristics of the names of its citizens. The central Betawi community has a characteristic name that is influenced by Islam and its familiarity, both for women's names and male names [12]. The "Belum Selesai" story contains names that describe them: Kosim, Fatma, Amsar, and Mak Minah. These are names from the family of the Prophet Muhammad. Other names are Ayup, Karim, Sahri, Sairun, and Sinah which represent the moslem names from the other prophet.

Whereas the suburban Betawi community which borders West Java and Banten uses names that are influenced by Sundanese and Javanese such as Acah, Mimin Sulastri, Masesun, and Sanip.

The name that is often used by Betawi people is Mamat, called Mat. This word comes from Muhammad. To prevent mistakes, the title is usually used behind the name Mat. So as I know there was someone who is called "Mat Topi" (Mat Hat) because his ears looked like rats while those with big eyes bulging were called "Mat Belo". The story of "Menimbang Berat" tells the story of a character who was previously called Mat Kurus (Mat the Skinny) then replaced by Mat Gagal (The Fail Mat) because he was once failed to commit suicide.

The most commonly used call or pronoun in the Betawi people's conversations is ana (me), and ente (you) who come from Arabic which are widely used in this story.

The Betawi community is known for obedience to religious orders. Ardan described this in the story "Bang Senan Mau ke Mekah" and "Sanip Membuat Lelucon." Bang Senan and Sanip are images of devout Betawi Muslims. They have the principle of giving priority to the hereafter compared to the world. By holding tight to religion, life will be a blessing, a survivor of the world and the hereafter. Bang Senan only wants his child to be smart in ngederes (reciting the Qur'an) that he prefers his son to recite, enter the madrasa, rather than going to school. He reasoned, "... I want to go to school so I can make it right, please believe it. Ente knows the children themselves now, ude lupe igame. Leave the service Watch! Take a walk! Maen Perempuan! [13].

Schools, especially for girls, are not a priority for the Betawi people. Even though her teacher thought "her brain was runny", Tinah left her school because his father argued, "Women don't need to go to school.
As long as she is a smart cook, it is easy to get men. You go to high school, to the kitchens too [13]."

In addition to being known for being honest and easy to give debt, Bang Senan does not sell beer which he considers unclean. When selling beer, Bang Senan felt his efforts were not blessed so he did not get progress. Therefore, he only sells coffee, cigarettes, banana cakes and other stuff from food stalls.

The Betawi people have a unique drink, which is bir pletok. Although using the word beer, this drink is not intoxicating because they come from various spices and have health benefits.

While Sanip, even though he was unemployed he did not want to leave the pray, especially praying five times. According to him, it's better to have fun in the hereafter than to be infidels. Even though someone is rich in the world, but in the death it will be burned by the fire of hell because during his life he is only thinking of the materiel. Thanks to his determination and surrender to God, he finally accepted a job in Jakarta City.

Obedience to God was also shown by the figure in "Rekaman". These figures, despite experiencing poverty, have never done illegal work. Every drum and azan sound was heard, he always came to the mosque near his house.

In addition to those who from their youth have been religious, in "Seberapa Baik Tuhan Tertawa" tells a story of Tinah's father who has converted in his old age. He is even more fanatical than the one who has always learnt religion since they were a little boy. Every Maghrib prayer comes, he went to the mosque and recited while waiting for the evening prayers to come. When he was young, he was a famous hero, loved to toy around women, and a bouncer. Reminded of his idiocy when he was young, he often told young people all to advocate and teach them not to do the same. Even so, he prefers pious people and diligently worshipping since he was young.

So did the kids, even though they were playing with salty gala and gerondong nenek, the local game of the children of Betawi, they dispersed themselves and stopped the game when the drum of the call to prayer arrived.

Many Betawi people live by selling things. This was exemplified by the Prophet and his companions. Including the spreaders of Islam to the archipelago in the early days, this is evident from the many markets around Betawi. Therefore, there are many markets in Betawi and so many places use the names of days such as Pasar Senen, a place that is the background of most of the stories in this book. People in the short story collection chose to sell a livelihood for people in several stories such as coffee sellers ("Bang Senan Naik Haji"), oil and cigarette sellers ("Bulan Menyaksikan") and meat sellers, cendol (traditional drink), vegetables in Kwitang ("Rekaman") and milk sellers ("Fajar Pagi [Fragmen Rumah Tak Berpintu]"). Among the sellers, meat sellers are among those who disappeared from the street circulation in Jakarta today. In the past, butchers were selling using bicycles 
behind them or on their pillion, they were placed in wooden boxes or large aluminum bottles filled with meat.

The widening development of the City of Jakarta caused the livelihoods of the Betawi people to change. Therefore, the business in the service was taken by the Betawi people, among whom were interesting rickshaws. The typical Betawi term is usually used by rickshaw pullers such as narik (slurp), gantian (reserve or substitute), and nembak (carrying cargo with other people's rickshaws) found in this short story collection.

Behind the religious side of the Betawi people, Ardan also displays the other side of the Betawi people. "Mulutnya Komat Kamit" tells about Japra, a rickshaw puller who is considered to be in a wrong mind. Even though he often muttered unclearly, he was known as an honest person. In addition to deposits, he honestly returned the wallet of the passenger that was left in his rickshaw. When he pulls a rickshaw, he slowly drives the rickshaw.

Mirin in "Es Krim" suddenly went crazy because of his wife's death. When he was killed by his wife who had been ill before, he only received a salary from the workshop where he worked. His newly received salary, he spent with Miran, his son, to eat at the restaurant "Ratna" and ordered food and ice cream.

The dark side of the Betawi people can be seen in the story "Mulutnya Komat-Kamit". In that story Ardan describes Betawi people who have a fondness for playing (gambling), drunk (drinking beer) and spending in the shipyard on new moon nights or Saturday nights with ronggeng or doger.

In that circle, the ronggeng shook their bottoms, sometimes fast, sometimes slow. Accompanied by gamelan, they sang songs as requested by visitors such as "Gaplek", "Ucing-ucingan", "Geboy", "Ujang Boin", and "Waru Doyong". In addition, they were singing with the men who were already unsteady, hovering over the influence of drinks. One of the places used by these circles is a road between Senen Station and a dead-end railway on Senen Lama. Before Governor Ali Sadikin relocated to Kramat Tunggak, the area was known as "Planet Senen" and the place of "localization" from late afternoon until dawn.

The ronggeng came from the buffer area of Jakarta who came to earn a living while waiting for the harvest. If the harvest arrived they returned to their villages to reap the coolies. She is in "Soto Mih" Ronggeng from Rengas, Banten. Aside from doing ronggeng, he also became a prostitute like Tasmi in "Oh, Tasmi", the prostitute sought by Mansur to his rented room in a narrow and muddy alley.

\section{CONCLUSION}

Such is the Islamic representation of the Betawi Society in a collection of Terang Bulan, Terang di Kali. Betawi community is mostly with various professions such as pedicab drivers, ice traders, shop owners, beggars, ronggeng, babu (housemaid), and the image include self-identity, education chosen, attitude to life that is in accordance with Islamic teachings and other habits. However, behind the picture of Islam displayed by the Betawi people, there are dark sides of some people from the community found in this collection of short stories. Such is the Islamic representation of the Betawi Society in a collection of Terang Bulang Terang di Kali: Cerita Keliling Jakarta by SM Ardan. Local colors is therefore important to accentuate the mental and social condition of the people in a certain society. Even so, local colors in a story should be examined carefully as it is not just a reality being portrayed by the author, but also it shows the vision of the author of the society he portrayed.

\section{ACKNOWLEDGMENT}

We would like to extend our gratitude to several parties, especially the Institute for Research and Community Service (LP2M) of Syarif Hidayatullah Islamic State University Jakarta and our Faculty who have given us the opportunity and facilities to present this article in international forum. With these opportunities and facilities we can ultimately learn a lot and meet other good opportunities.

\section{REFERENCES}

[1] Marahimin, Ismail. 2010. Menulis Secara Populer. Jakarta : Pustaka Jaya.

[2] Murniah, Dad. 2007. "Warna Lokal dalam Sastra Indonesia" dalam Amin Sweeney (ed.) Keindonesian dan Kemelayuan dalam Sastra. Depok : Desantara.

[3] Bahadur, Ishadi. 2014. "Peran Novel-novel Indonesia Warna Lokal dalam Upaya Membangun Keragaman Budaya" dalam Prosidng Semainar Pendidikan Berbasis Keragaman Budaya, Sumbangan Bahasa dan Sastra Indonesia. Prosiding Seminar Internasional. Jakarta : Fakultas Ilmu Tarbiyah dan Keguruan, UIN Syarif Hidayatullah, Jakarta.

[4] Mahayana, Maman. 2015. Kitab Kritik Sastra. Jakarta : Yayasan Pustaka Obor Indonesia.

[5] Stuart Hall, Stuart. 2003. "Representation: Cultural Representation and Signifying Practices", Sage: London

[6] Barker, Chris. Cultural Studies: Teori dan Pratik. Yogyakarta: Bentang, 2005.

[7] Damono, Sapardi Djoko. 1979. Sosiologi Sastra Sebuah Pengantar Ringkas, Jakarta: Pusat Pembinaan dan Pengambangan Bahasa, Departemen Pendidikan dan Kebudayaan

[8] Endraswara, Suwardi. 2008. Metodologi Penelitian Sastra: Epistemologi, Model, Teori, dan Aplikasi. Yogyakarta: Media Pressindo.

[9] Siswanto, Wahyudi. 2008. Pengantar Teori Sastra. Jakarta: Grasindo, 2008.

[10] Hart, James D., and Philip Leininger. 1995. Oxford Companion to American Litterature. Berkeley : Oxford University Press USA.

[11] Ratna, Nyoman Kutha. 2010. Teori Metode, Teknik Penelitian Sastra. Yogyakarta: Pustaka Pelajar.

[12] Alkatiri, Zeffry. 2012. Jakarta Punya Cara. Jakarta : Masup Jakarta.

[13] Ardan, S.M. 2007. Terang Bulan Terang di Kali : Cerita Keliling Betawi. Jakarta : Pustaka Jaya. 